\title{
THE ANALYSIS OF ENGLISH-INDONESIAN TRANSLATION AT \\ WELCOME ON BOARD SECTION ON GARUDA MAGAZINE
}

Yuli Kuswardani

\begin{abstract}
The main aim of this study is to explain the quality of translation of Garuda Magazine from English into Indonesian. The analysis concerns on accuracy, clarity/clearness and naturalness of translation of Garuda Magazine from English into Indonesian. The research method uses qualitative descriptive and the type of research is content analysis. This research takes the section "Welcome on Board" page 12 on Garuda Magazine November 2008 edition as source of data. The result of the research shows that 3 data (15,79\%) are less accurate and 84,21\% or 16 sentences are accurate; 3 data (15,79\%) are less clear and 84,21\% or 16 sentences are clear; 5,26 \% or 1 sentence is unnatural, 36,84\% or 7 sentences are less natural and $57,90 \%$ or 11 sentences are natural.
\end{abstract}

\section{A. Introduction}

Language is an important way of communicating with the people. The people use language to let others know how they feel and what they need. Sometimes, people in another place feel difficult to understand the meaning of what they are reading or talking with others. In such a case, they need the translator to support the purposes that they want to reach.

The way to catch and understand meaning is by translating the text. Translation can be defined as transferring the meaning of the source language into the receptor language (Larson, 1984: 3). It means that translation is the process of transferring meaning from one language to another language.

In translation, one thing that must be considered is the quality of translation. To know the quality of translation means analysing the translation result. In this study, the researcher analyzes the quality of translation on Garuda Magazine. Overall, the researcher needs to know the quality of translation in this magazine, whether it is readable, accurate, natural or not. The quality of 
translation can be seen from its clarity, accuracy and naturalness. Larson (1984: 485-488) describes that a good translation must fulfill three criteria: accuracy, clarity and naturalness.

In this study, the researcher wants to analyze the quality of translation. So, the problems of statement in this research can be described as follows: how are the accuracy, clarity/readability and naturalness at "Welcome on Board" section on Garuda Magazine November 2008 edition.

\section{B. Review of Related Theories \\ a. Definition of Translation}

Generally, the term of translation refers to the transferring meaning from the source language into the target language. In this study, the researcher tries to describe the definition of translation from two different experts. First expert is Nida and Taber and the second one is Larson.

Nida and Taber (1969: 12) argue that translation is the process of produce the equivalent that is the meaning and style closer the source language. It means that a translator tries to translate the text with the meaning and style closer with the source language.

While Larson (1984: 3) states that in translating text the translator should consider the lexicon, grammatical structure, communication situation and cultural context of the source language text in order to get his/her good translation. So, the reader can easily understand the meaning of the text being translated by the translator.

In summary, the translation is the process of producing meaning from source language to target language by finding the closest equivalent in terms of meaning and style. 


\section{b. Process of Translation}

According to Nida and Taber (1969: 33) there are three activities in translation process: analyzing, transferring and restructuring. These activities will be described as follows:

a. Analyzing is the process in which the surface structure is analyzed in terms of the grammatical relationship and the meaning of the words and combinations of words.

b. Transferring is the process in which the analyzed material is transferred in the mind of the translator form one language to other language.

c. Restructuring is the process in which the transfer material is restructured in order to make the final message fully acceptable in the receptor language.

\section{c. The Criteria of Good Translation}

Larson (1984: 485-487) states that there are criteria of good translation: accurate, clear and natural. Those criteria will be described as follows:

1. Accurate

The meaning of the source language text should be transferred in the receptor language accurately. There should be no deviation of meaning in receptor language.

2. Clear

The result of translation should express all aspect of the meaning in a way that is readily understandable to the intended audience.

3. Natural

The translation must sound natural. It does not seem like a translation.

\section{d. Parameter on Translation Assessment}

Roswita Silalahi (2009: 119-120) simplifies the parameter on translation assessment from Rochayah Machali. It is described as follows: 
1. Accuracy of translation:

\begin{tabular}{|c|l|l|}
\hline Skala & \multicolumn{1}{|c|}{ Definisi } & Kesimpulan \\
\hline 3 & $\begin{array}{l}\text { Makna kata, frasa, klausa, dan kalimat bahasa } \\
\text { sumber dialihkan secara akurat ke dalam } \\
\text { bahasa sasaran; sama sekali tidak terjadi } \\
\text { distorsi makna }\end{array}$ & Akurat \\
\hline 2 & $\begin{array}{l}\text { Sebagian besar makna kata, frasa, klausa, dan } \\
\text { kalimat bahasa sumber sudah dialihkan secara } \\
\text { akurat ke dalam bahasa sasara. Namun masih } \\
\text { terdapat distorsi makna atau terjemahan makna } \\
\text { ganda/ taksa atau ada makna yang dihilangkan, } \\
\text { yang mengganggu keutuhan pesan. }\end{array}$ & akurat \\
\hline 1 & $\begin{array}{l}\text { Makna kata, frasa, klausa, dan kalimat bahasa } \\
\text { sumber dialihkan secara akurat ke dalam } \\
\text { bahasa sasaran atau dihilangkan/ deleted }\end{array}$ & Tidak akurat \\
\hline
\end{tabular}

2. Naturalness/acceptibility of translation:

\begin{tabular}{|c|l|l|}
\hline Skala & \multicolumn{1}{|c|}{ Definisi } & Kesimpulan \\
\hline 3 & $\begin{array}{l}\text { Terjemahan terasa alamiah; istilah teknis yang } \\
\text { digunakan akrab bagi pembaca; kata, frasa, } \\
\text { klausa, dan kalimat yang digunakan sudah } \\
\text { sesuai dengan kaidah-kaidah bahasa Indonesia }\end{array}$ & \\
\hline 2 & $\begin{array}{l}\text { Pada umumnya terjemahan sudah terasa } \\
\text { alamiah; namun ada sedikit masalah pada } \\
\text { penggunaan istilah teknis atau terjadi sedikit } \\
\text { kesalahan gramatikal }\end{array}$ & Kerterima \\
\hline 1 & $\begin{array}{l}\text { Terjemahan tidak alamiah atau terasa seperti } \\
\text { karya terjemahan; istilah teknis yang digunakan }\end{array}$ & Tidak \\
berterima
\end{tabular}




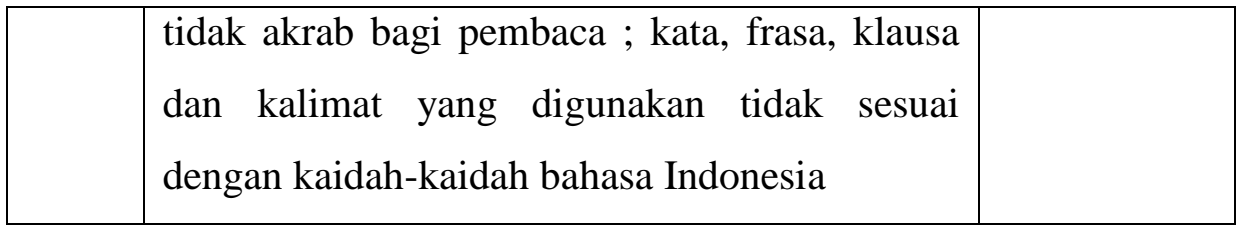

3. Clarity/readibility of translation:

\begin{tabular}{|c|l|l|}
\hline Skala & \multicolumn{1}{|c|}{ Definisi } & Kesimpulan \\
\hline 3 & $\begin{array}{l}\text { Kata, frasa, klausa, dan kalimat terjemahan } \\
\text { dapat dipahami dengan mudah oleh pembaca }\end{array}$ & $\begin{array}{l}\text { Tingkat } \\
\text { keterbacaan } \\
\text { tinggi }\end{array}$ \\
\hline 2 & $\begin{array}{l}\text { Pada umumnya terjemahan dapat dipahami } \\
\text { oleh pembaca: namun ada bagian tertentu yang } \\
\text { harus dibaca lebih dari satu kali untuk } \\
\text { memahami terjemahan }\end{array}$ & $\begin{array}{l}\text { Tingkat } \\
\text { keterbacaan } \\
\text { sedang }\end{array}$ \\
\hline 1 & Terjemahan sulit dipahami oleh pembaca & $\begin{array}{l}\text { Tingkat } \\
\text { keterbacaan } \\
\text { rendah }\end{array}$ \\
\hline
\end{tabular}

\section{Research Method}

\section{a. Type of Research}

This study is qualitative research. The researcher explores the meanings of written document, namely magazine. In this research, the researcher analyzes the quality of translation result at "Welcome on Board" section November 2008 edition.

\section{b. Technique of Collecting Data}

In this research, the researcher uses content analysis. According to Berg (2009: 341), "In content analysis, researcher examines artefact of social communications. Typically, these are written documents or transcription of recorded verbal communication". In other word, this technique is used to examine 
artefact of social communication, such as written documents or transcription of recorded verbal communications.

In this study, the researcher uses content analysis to collect the data because the source of data is written document, Garuda Magazine November 2008 edition.

\section{c. Source of Data}

The source of data in this study is "Welcome on Board" section page 12 on Garuda Magazine November 2008 edition.

\section{d. Technique of Analyzing Data}

The researcher uses some steps to analyze the data based on Miles and Huberman theory: data reduction, data display, and conclusion drawing/verification (1984: 21-22).

\section{Data finding and discussion}

\section{a. The Accuracy Percentage Table}

\begin{tabular}{|c|l|c|c|}
\hline No. & \multicolumn{1}{|c|}{ Quality of Translation } & Amount (sentence) & Percentage (\%) \\
\hline 1. & Accurate & 16 & 84,21 \\
\hline 2. & Less accurate & 3 & 15,79 \\
\hline 3. & Inaccurate & - & - \\
\hline \multicolumn{2}{|c|}{ Total } & 19 & 100 \\
\hline
\end{tabular}

The table above shows that 16 sentences of translation result $(84,21 \%)$ are accurate and 3 sentences $(15,79 \%)$ are less accurate (number 12, 16, and 18). One of the examples is the sentence number 12. It is described as follows:

SLT: Flying can dehydrate you, so drink of non-alcoholic liquid.

TLT: Berada di ketinggian dapat menyebabkan dehidrasi, sebaiknya Anda mengkonsumsi cukup minuman non-alkohol.

Based on Oxford Learner's Pocket Dictionary, the word "flying" has the meaning "move through the air as a bird does, or in an aircraft", whereas the 
meaning in Indonesian based on An English-Indonesian Dictionary is "naik kapal terbang; terbang". In TLT, the translator translates the word "flying" into "berada di ketinggian". It is less accurate because the meaning is deviated and it is not suitable with the context, so it reduces the unity of message.

\section{b. The Clarity/Clearness Percentage Table}

\begin{tabular}{|c|l|c|c|}
\hline No. & \multicolumn{1}{|c|}{ Quality of Translation } & Number of sentence & Percentage (\%) \\
\hline 1. & Clear & 16 & 84,21 \\
\hline 2. & Less clear & 3 & 15,79 \\
\hline 3. & Unclear $\quad$ Total & 19 & - \\
\hline \multicolumn{2}{|c|}{} & & 100 \\
\hline
\end{tabular}

The table above shows 16 sentences $(84,21 \%)$ of the translation result are clear and 3 sentences $(15,79 \%)$ are less clear (number 1, 2, and 15). It can be seen from the example below:

\section{SLT: Welcome aboard}

\section{TLT : Selamat datang.}

Based on Oxford Learner's Pocket Dictionary "aboard” means "on or into a ship, aircraft or train or a bus". The meaning in Indonesian based on An English- Indonesian Dictionary is "di (atas, dalam); naik". In TLT, the translator translates "welcome on board" into "selamat datang". It is less clear because there is certain part that should be read more than once to make the reader understand with the meaning. It will be better if "welcome on board" translated become "selamat datang di penerbangan kami" regarding the context "in flight".

\section{c. The Naturalness Percentage Table}

\begin{tabular}{|c|l|c|c|}
\hline No. & \multicolumn{1}{|c|}{ Quality of Translation } & Number of sentence & Percentage (\%) \\
\hline 1. & Natural & 11 & 57,90 \\
\hline 2. & Less natural & 7 & 36,84 \\
\hline 3. & Unnatural & 1 & 5,26 \\
\hline \multicolumn{2}{|c|}{ Total } & 19 & 100 \\
\hline
\end{tabular}


The tables above shows that 11 sentences $(57,90 \%)$ are natural, 7 sentences $(36,84 \%)$ are less natural (number 3, 5, 10, 12, 13, 14 and 16) and 1 sentence $(5,26 \%)$ is unnatural (number 2$)$. The example is given below:

SLT: Do not leave valuables behind during transit stops and remember to check that you have all your belongings when you disembark.

TLT: Jangan meninggalkan barang-barang berharga selama transit dan disarankan untuk meneliti kembali barang bawaan Anda ketika akan meninggalkan pesawat.

Based on Oxford Learner's Pocket Dictionary, the word "check" means "make sure of something by examining or investigating; examine something to make sure it is correct, safe, satisfactory, etc". In the target language context, it means "mengirimkan, menitipkan, menyimpan, memeriksa". In TLT, the word "check" simply translated into "meneliti". It will be natural if it is translated into "memeriksa".

\section{E. Conclusion}

1. The Accuracy of "Welcome On Board" section on Garuda Magazine November 2008 edition

It is found that $15,79 \%$ or 3 sentences are less accurate. The meaning of source language text has not been represented in TLT.

2. The Clearness of "Welcome On Board" section on Garuda Magazine November 2008 edition

It is found that $15,79 \%$ or 3 sentences are less clear and $26,31 \%$ or 5 sentences are less clear. Translation result can be easily understood by the readers but there is certain part that should be read more than once to understand the meaning.

3. The Naturalness of "Welcome On Board" section on Garuda Magazine November 2008 edition 
It is found that $36,84 \%$ or 7 sentences are less natural and $5,26 \%$ or one sentence is unnatural. The use of translation equivalent in TLT is less appropriate.

\section{F. References}

Berg, Bruce L. 2009. Qualitative Research Methods for The Social Sciences (7 $E d)$. Boston: Pearson Education, Inc.

Crabtree, B. F. and William R. Miller. 1992. Doing Qualitative Research. London: SAGE Publications

Fraenkel et al. 1993. How to Design and Evaluate Research and Education (8 Ed). Singapore: McGraw-Hill, Inc

Larson, Mildred L. 1984. Meaning-Based Translation. Lanham: University Press of America, Inc

Rochayah Machali. 2009. Pedoman Bagi Penerjemah: Panduan Lengkap Bagi Anda Yang Ingin Menjadi Penerjemah Profesional. Bandung: Kaifa

Miles, M. B. and Huberman A. Michael. 1984. Qualitative Data Analysis: A Sourcebook of New Methods. London: SAGE Publications

Nida, E. A. and Charles R. Taber. 1969. The Theory and Practice of Translation. Leiden: E.J.Brill

Silalahi, Roswita. 2009. "Dampak Teknik, Metode, dan Ideologi Penerjemahan Pada Kualitas Terjemahan Teks Medical-Surgical Nursing Dalam Bahasa Indonesia”. Disertasi. Program Pascasarjana. Universitas Sumatera Utara. 